УДК 124.5:321.011.5]:316.3(=161.2)

DOI 10.35423/2078-8142.2019.5-6.02

С. О. Рябека

здобувач Начіонального педагогічного університету імені М. П. Драгоманова

м. Київ, Украӥна e-mail:riabeka20@ukr.net ORCID: https://orcid.org/0000-0002-9812-0574

\title{
ПРОБЛЕМИ УТВЕРДЖЕННЯ ЄВРОПЕЙСЬКОЇ ДЕМОКРАТИЧНОЇ АКСІОЛОГІї В УКРАЇНСЬКОМУ СУСПІЛЬСТВІ
}

Зміинення незалежності украӥнської держави пов'язане з необхідністю вирімення низки нагальних економічних, політичних, соціокультурних проблем. У иарині політики ці проблеми концентруються навколо поняття «демократія». Зміинення демократії неодмінно посилить відкритість украӥнського суспільства, сприятиме звеличенню свободи. Автор статті обгрунтовує тезу, що коли йдеться про утвердження в Україні демократично-правового суспільства, інститутів, правил і процедур, одним з фундаментальних питань $\epsilon$ повноцінне закріплення європейських демократичногуманістичних иінностей у суспільній свідомості, ментальності украӥнців. Відзначається, що історично украӥнці є європейською начією, однак протягом тривалого часу перебували у складі державного утворення, в якому аксіологічні орієнтири значно різнилися від європейських, що, звісно, гальмувало інтеграчію Украӥни в єдину сім'ю європейських народів. У статті аналізуються різні проблеми світоглядно-аксіологічного стану украӥнського суспільства, які перешкоджають поступу до європейських иінностей демократичного суспільства.

Ключові слова: людина, цінності, культура, виховання, демократія, європейська ідентичність. 
Як йдеться в головних нормативно-правових документах, що визначають напрями розвитку української держави, зокрема у Конституції України, європейський вибір - це стратегічний вибір України. I це не випадково, як відзначає В. П. Андрущенко, адже «історично Україна завжди була в Свропі. Ментальність українців європейська. Стиль життя українців, мислення і світогляд європейські. На жаль євроінтеграційні процеси відбуваються повільно і суперечливо. Дехто намагається вибудувати штучні бар'єри, загострити суперечки, спричинити конфлікти. Але Україна рано чи пізно здолає всі перепони й посяде достойне місце серед народів європейського простору як надійний і цікавий з погляду культурних традицій партнер» [1, с. 147].

Водночас, шлях утвердження демократичних цінностей європейської культури на теренах України є досить проблематичним. Проблемами утвердження європейської демократичної аксіології українського суспільства займались українські та зарубіжні дослідники, серед яких В. П. Андрущенко, А. Аслунд, О.В.Бабкіна, В. Буцевицький, В. В. Кривошеїн, Н.В.Лютко, О. П. Полисаєв, О. Траверсе та ін. В. Д. Воднік розглядав питання щодо ментальних трансформацій у сучасному українському суспільстві. Т. Б. Мадрига досліджує європейські цінності та ціннісні орієнтації українського суспільства та проблеми їх співвідношення.

Метою цієї статті є розгляд та аналіз проблеми утвердження європейської демократичної аксіології в українському суспільстві.

На нашу думку, в України немає іншого шляху розвитку та становлення як самостійної держави, крім наполегливого просування в бік Свропи. Ми обстоюємо щодо цього руху оптимістичну точку зору, незважаючи на наявність у нашої країни суттєвих як внутрішньодержавних, так і геополітичних проблем і перепон. Сьогодні потреба демократії для українського трансформаційного суспільства є питанням фактичного збереження України в якості держави, нації, соціокультурного суб'єкта світових процесів. Саме на аналізі цієї потреби зосередимо увагу у цьому дослідженні.

Як відзначає М. Михальченко, з аксіологічної точки зору Україна, безперечно, є «розділеною цивілізацією». До того ж цей розділ відбувається не за географічномим, а феноменологічнокультурномим принципом. 3 одного боку, українцям властиві такі 24

Institute of Philosophy of H. S. Skovoroda of NAS of Ukraine 
риси європейської ментальності, як демократичність та людиноцентричність. Але з іншого, ми ще тривалий час не будемо спроможні позбавитися тих патерналістських та етатистських звичок, поглядів, життєвих пріоритетів, які глибоко вкорінилися як наслідок тривалого перебування у складі Російської імперії та СРСР. «Поступово відроджуються традиційні риси української національної культури - народоправство, толерантність, ліберальне ставлення до держави (держава для людини й нації, а не людина й нація для держави). Одночасно спостерігаються прояви его- і громадоцентризму, які притаманні українській ментальності. За цивілізаційнокультурними ознаками сучасній Україні загалом притаманна прихильність до західноєвропейських політичних цінностей, хоча помітну роль у політичному житті народу відіграють риси ментальності й культури, що властиві Східній цивілізації. Імперський та радянський періоди історії України обумовили відповідне ставлення до держави (етатизм та патерналізм), ії глави (установка на харизматичного лідера), політичних прав і свобод особистості (підданство, общинність), системи влади (авторитаризм), ролі церкви в політичному житті суспільства (підпорядкованість церкви державі)» [2, с. 46]. Отже, в такій складній світоглядно-аксіологічній ситуації український народ має обрати пріоритети свободи, відповідальності, солідарності, гідності і права. Цей вибір значно ускладнюється через жебрацький стан національної економіки та загальну бідність широких верств населення. Крім того, існує значна кількість перепон, що мають глобальний характер.

Щодо цього зауважимо, що на сучасному етапі розвитку інформаційно-технологічної цивілізації людині важко займатися самовихованням, ціннісною самоосвітою, адже їй пропонується безмежна кількість образів дій, етичних та естетичних варіацій. При цьому демократично-правовий аксіологічний вибір українців має бути здійсненим у найближчій перспективі. Така потреба існує 3 двох причин. По-перше, тягар колишніх ціннісних патернів (імперського і комуністичного) може призвести до повернення України у простір безпосереднього і потужного впливу Росії. По-друге, Свропа 3 часом може виявитися просто недосяжною для відсталої периферійної країни. «Українське суспільство не має можливості вчитися на своїх і чужих помилках так довго, як деякі країни в ми- 
нулому, адже світова динаміка суспільних трансформацій набула такого прискорення, що навіть прогаяне десятиліття здатне позбавити країну, що наздоганяє, історичної перспективи та приректи ії на маргінальне існування» [3, с. 33]. Отже, потреба демократії для українського трансформаційного суспільства $є$ не лише проголошеним орієнтиром, а й нагальною потребою, від якої фактично залежить саме виживання українців як самостійної, автентичної, самодостатньої та цікавої для інших країн європейської нації.

У сучасному глобалізованому світі успіх певної країни значною мірою залежить від того, до якого геополітичного кластеру вона відноситься. Україна, на жаль, опинилася на перетині таких кластерів, які різняться не лише в економічній чи політикостратегічній, а й у світоглядно-ціннісній сфері. Саме вибір демократичного світогляду є ключовою умовою приєднання українців до цілісності (нехай навіть не у формальному плані СС) європейських народів. «Чітке визначення геополітичних пріоритетів, консолідація в масовій свідомості базових національних інтересів є одними 3 найважливіших передумов стабільного розвитку будь-якої сучасної держави. У більшості випадків геополітичні пріоритети виводяться з базових цінностей суспільства, таких як виживання, свобода, демократія, економічний добробут розвиток, соціальнокультурні традиції і орієнтації, інші внутрішні (національна ментальність і домінуюча ідеологія, економічна система та інші) та зовнішні (міжнародне середовище, в тому числі геополітичне, союзи блоки історичний досвід і традиції міжнародних відносин та ін.) параметри. Приналежність України до Свропи не можна заперечувати - це об'єктивна реальність, як і та, що український народ належить до сім'ї європейських народів» [4, с. 286]. Однак складний та суперечливий масив національної аксіології та ідеології призводить до суттєвих ускладнень на шляху євроінтеграції. Українці на рівні цінностей все ж не повністю ідентифікують себе як європейці. Для такої повноцінної самоідентифікації має бути завершений проект наскрізної демократизації соціуму, держави, громадянського суспільства.

У цьому й полягає потреба демократії для українського трансформаційного суспільства. Показово, що в розбудові держави на рівні гасел, партійних програм та навіть загальнодержавних доку26

Institute of Philosophy of H. S. Skovoroda of NAS of Ukraine 
ментів конституційного й законодавчого рівнів демократичне влаштування держави є фундаментальним постулатом і пріоритетом. «Конституція України дуже чітке підтвердження принципів плюралістичної демократії. Вона проголошує народ сувереном та єдиним джерелом влади. Вона надає громадянам індивідуальні права i свободи, але механізми гарантування цих прав далекі від ефективних» [5, с. 9]. А демократія проявляється саме у практичній реалізації зафіксованих правових гарантій. На цьому шляху українці зробили потужний ривок, здійснивши дві антикорупційні та демократично орієнтовані революції. Але в буденній практиці державної, громадської, правозастосувальної тощо дії ми не перетворилися на демократів, адже аксіологічно, ментально, культурно не готові до цього.

Аналізуючи пострадянську історію нашої держави можна стверджувати, що Україна періодично демонструє потребу в демократії, але на регулярній основі, в повсякденному політичному i громадському процесі, гальмує і скочується в авторитаризм. Як відзначає Пол Д'Аньєрі: «У 1994 році Україна показала себе найдемократичнішою країною серед пострадянських республік. Відбувся мирний трансфер влади від одного президента іншому. До конкурентної виборчої процедури були допущені всі претенденти. Це вигідно вирізняло Україну на тлі Росії 1993 року. Однак уже в 1999 році цілком проявили себе потужні авторитаристські риси. Адміністрація президента Кучми застосувала всі можливі засоби, щоб позбавити вибори конкурентності. Тепер почали застосовуватися терміни «делегативної демократії» та «конкурентного авторитаризму» щодо української держави» [6, с. 20]. Так само відбувалися відкочування до посилення авторитаризму після пафоснодемократичних Майданів. Чому українці наприкінці третього десятиліття незалежності так і не змогли утвердитися в якості демократично-правової держави? На нашу думку, головна перепона тут перебуває саме у площині аксіологічної розмежованості, коли в ціннісно-феноменологічній матриці змушені уживатися свободолюбство і патерналізм, громадський активізм і етатизм, прагнення до законності, права і потужний непотизм, що корупційно просто знищує державу. 
Україна особливо гостро переживає цю аксіологічну амбівалентність. Більшість республік колишнього СРСР вже визначилися 3 подальшими перспективами розвитку: демократичними, авторитарними, тоталітарними. А в соціально-ціннісному полі українців поєднується багато протилежних аксіологічних установок. Тоді як реальна демократична трансформація може бути повноцінно здійсненою лише за умов чіткої пріоритетності цінностей свободи, відповідальності, права, гідності, миролюбства, толерантності тощо. «Особливість розвитку суспільств перехідного типу (від однієї моделі розвитку до іншої) пов'язана зі змінами як об'єктивних умов, так і соціальних пріоритетів, цінностей та орієнтацій. Трансформування світоглядних орієнтацій тривалий час перебуває в стані амбівалентності (поєднання протилежних, суперечливих тенденцій), руйнування попередніх світоглядних стереотипів i формування нової або реконструкції існуючої системи цінностей. За цих умов значно ускладнюється орієнтація громадян у політичному житті суспільства, у визначенні індивідуальних позицій до тих чи інших суспільних процесів. Ми будуємо демократичне суспільство, а демократія - це особлива культура ставлення до суспільного життя, яка грунтується на визнанні фундаментальної гідності людини» [7, с. 318]. Питання успішної трансформації, що потягне за собою інтенсифікацію процесу євроінтеграції України, перебуває виключно у площині цінностей, які домінують у нашому соціумі. Поки зберігається домінування патерналістської та непотистської свідомості, важко сподіватися на те, що наша країна сприйматиметься в якості повноцінного суб'єкта європейського демократичноправового простору.

Таким чином, потреба демократії для українського трансформаційного суспільства є зрозумілою і очевидною, але реальна демократизація суттєво гальмується через світоглядно-аксіологічну неготовність українців. Національна свідомість тривалий час перебувала під потужним тиском тих феноменологічних, аксіологічних, соціокультурних установок, які є далекими від демократії. «Відсутність демократичних передумов у нашій країні не могла не відбитися на ментальності українського народу. Тривале панування тоталітаризму деформувало уявлення про демократію. Необхідний довготривалий досвід успішної діяльності демократичних інститу28

Institute of Philosophy of H. S. Skovoroda of NAS of Ukraine 
тів, щоб у національному характері утвердились такі риси демократії, як терпимість, готовність до співробітництва 3 людьми, що мають інші політичні та ідейні погляди, повага прав особи і меншин, усвідомлення громадянами принципу «держава для громадянина», дотримання закону усіма громадянами, незалежно від посади, статусу тощо» [7, с. 318]. Чи є в України шанс на такий досвід, адже він може з'явитися лише після проведення реальних демократизаційних реформ, подолання надмірної корупції? Поки що не лише на цьому шляху було здійснено замало кроків, а й у світоглядно-ціннісній матриці українців не ствердилися пріоритети демократично-правового мислення.

У зв'язку з цим актуалізується проблематика дослідження основних викликів на шляхах становлення демократії в Україні. Тут, на нашу думку, проблема поділяється на два взаємопов'язаних блоки. Перший має практичний характер і виявляється в інституційній, процедуально-правовій, управлінській, законодавчій, економічній дисфункціональності української держави і суспільства. У цьому контексті Андерс Аслунд відзначає, що «Україна страждає від трьох взаємопов'язаних хвороб. По-перше, можливості захисту фундаментальних прав людини далекі від персональних та соціальних очікувань на закон і порядок. По-друге, українські уряди край малоефективні. По-третє, корупція залишається край потужною та руйнівною» [8, с. 258]. Але цей блок проблем має під собою міцне підгрунтя, що і являє собою другий блок. Він виявляється у світоглядно-ціннісних орієнтаціях українців, які орієнтовані на корупційність, непотизм, антидержавницькі ідеологеми, культурну денаціоналізованість тощо. На нашу думку, саме зі світоглядно-аксіологічної сфери, яка становить основу сучасної української ментальності, випливають практичні проблеми неможливості розвитку власної держави, економіки, соціуму.

А звідси постають й інші проблеми. Наприклад, якщо українці спромоглися на два Майдани, то чому внаслідок них не відбулося якісних зрушень у демократизаційній та правовій сфері? Незважаючи ні на що, не відбулося революції у свідомості народу, в його аксіологічній сфері, не змінилися індивідуальні, громадські, суспільні орієнтації. Також у соціумі і політикумі не виникло елітного прошарку, що міг би позитивно вплинути на трансформацію 
аксіологічного простору українців. «Українська політична еліта лише певною мірою змінилася внаслідок революцій. Формально визнавши та частково зрозумівши принципи політичного життя за демократії, вона й далі демонструє неспроможність забезпечити верховенство закону і діяти за правилами демократичної політичної гри. Ї̈і групи відрізняються тільки мірою своєї незрілості для переходу до стійкої, консолідованої демократії» [3, с. 136]. А як засвідчує історія більшості суспільств, які здійснили успішний тривало-історичний чи реформаційно-трансформаційний перехід до демократії, головним імпульсом для зміни соціальних цінностей та орієнтирів завжди була позиція політичних, громадських, соціокультурних еліт.

Ключовим викликом на шляху становлення демократії в Україні, на нашу думку, є ціннісна розбіжність з досить суперечливих напрямів. Поступово набирає сили аксіологічна орієнтація на цінності європейські, демократичні, гуманістично-правові, але потужним залишається світоглядно-ментальний масив, сформований в імперські і радянські часи. У структуру останнього гармонійно вписані патерналізм, етатизм, прагнення до корупційного збагачення, меншовартість, прагнення до того, щоб бути таким, як усі. «Декларуючи євроінтеграційні прагнення, Україна, так чи інакше, рухається у напрямі утвердження гуманістично-демократичних цінностей. Однак особливість ціннісної ідентифікації сучасної України полягає в тому, що вона у культурному та цивілізаційному плані є і євразійською, і європейською державою, а зовнішньополітичні орієнтири на європейський простір тривалий час пригнічувались набутими завдяки комуністичному режимові рисами «євразійськості». Тому ціннісна система включає в себе, з одного боку, елементи патерналістських, етатистських, егалітаристських цінностей комуністичного минулого, а з іншого - демократичних, орієнтованих на індивідуалізм, інноваційність, конкурентоспроможність, самостійність в мисленні, виборі та діяльності, прагнення успіху і достатку тощо. Одночасно недостатньо сформовані, а в частини населення загалом відсутні такі цінності як згода, толерантність, громадянськість, які в транзитологічних теоріях виступають необхідною структурною передумовою консолідації демократії» [9, с. 100]. Отже, в аксіологічному полі українського суспільства, по суті, поєднують30

Institute of Philosophy of H. S. Skovoroda of NAS of Ukraine 
ся непоєднувані ціннісні імперативи та орієнтири. Така хаотична світоглядно-аксіологічна система є суттєвою перепоною на шляху розвитку справжньої демократії європейського типу. «Конгломеративна, неструктурована та неієрархізована система (скоріше сукупність) українських цінностей, що містить взаємовиключні елементи (індивідуалізм-колективізм, патерналізм - індивідуальна автономія, ринок-егалітаризм і т.і.) є значною перешкодою формування ціннісного консенсусу і системи суспільних цінностей, прийнятної для більшості населення. Такими безумовними цінностями, які структурують інші цінності, політичний простір і принципи політичних відносин, вчені називають свободу та людину як найвищу цінність» $[10$, с. 156]. Саме 3 огляду на останнє твердження можна розвивати певну оптимістичну модель аксіологічних трансформацій в українському суспільстві, адже національні традиції, культурний менталітет, побутова та громадська поведінка українців завжди були зорієнтовані на аксіологічний пріоритет свободолюбства та людиноцентризму. Без цих традиційних ціннісних основ важко взагалі було б сподіватися на наполегливий рух України до Свропи.

Але $є$ в традиційних українських цінностях й інші наративи, що скоріше заважають утвердженню європейської аксіології та справжній, а не декларативній демократизації. Одним з таких наративів є так зване кумівство, непотизм, що за останні десятиліття призвів до суттєвого погіршення якості людського капіталу в Україні. В абсолютній більшості сфер соціального, економічного та політичного функціонування держави і суспільства ключову роль відіграють не компетентність спеціалістів, а їх родинні зв'язки. Це особливо стосується національного політикуму. «Особливості української політичної еліти визначаються багатьма чинниками. Насамперед, це характер утворення національного істеблішменту. Найпоширенішим способом просування особистості «нагору» у вітчизняному політикумі є можливість стати членом команди, що працює на впливового політичного лідера. Іншими словами, типовою моделлю формування української політичної еліти є клієнтарна модель. Найбільша вада ії полягає в тому, що між такими лідерськими командами та всередині них постійно точиться відверта або прихована («підкилимна») боротьба (зазвичай 
боротьба «компроматів»)» $[11$, с. 65]. Важко собі уявити, що людина, яка отримала певний соціальний статус виключно завдяки зв'язкам, а не компетентностям, стане провідником демократичної, гуманістично-правової, аксіології і буде обстоювати цінності гідності, рівності, справедливості.«Відтак провідну роль в успішному просуванні кар'єрними сходинками відіграють не особисті чесноти, а належність до «команди», сім'ї, клану, соціальної групи. Саме вони «виштовхують на поверхню» потрібних їм лідерів» [12, с. 30]. На нашу думку, в цьому полягає одна 3 ключових перепон на шляху становлення справжньої європейської демократії в Україні. Даний виклик є дуже важливим і потужним саме через те, що непотизм і кумівство $є$ доволі вкоріненою українською звичкою, яка цілком відповідає національній аксіологічній матриці і лежить в іiі основі.

Усі ці виміри засвідчують значні проблеми, які постають на шляху утвердження європейської демократичної аксіології в українському суспільстві. Серед цих проблем вважаємо основними цивілізаційну розділеність за феноменологічно-культурномим принципом, наявність патерналістських та етатистських властивостей, успадкованих від попередніх етапів розвитку українського суспільства, що помножується на перебування на межі геополітичних кластерів, котрі належать до різних світоглядно-аксіологічних засад. Проблемність ситуації окреслюється ціннісною розділеністю між взаємосуперечливим світоглядно-аксіологічним напрямом домінуванням патерналістської та непотистської свідомості, аксіологічних орієнтацій на патерналізм, корупційність, непотизм, антидержавницькі ідеологеми, культурну денаціоналізованість тощо, 3 одного боку, а з іншого - європейською аксіологічною ідентичністю, що полягає в пріоритеті цінностей свободи, відповідальності, солідарності, права, гідності, миролюбства, толерантності, індивідуалізмі, інноваційності, конкурентоспроможності, самостійності. Такий розкол породжує стан, коли Україна опиняється в інституційній, процедуально-правовій, управлінській, законодавчій, економічній дисфункціональності української держави і суспільства, а це загрожує не лише поверненням України у простір безпосереднього і потужного впливу Росії, а й глобальним системним безнадійним відставанням від країн Першого світу. Моніторинг аксіоло32

Institute of Philosophy of H. S. Skovoroda of NAS of Ukraine 
гічних преференцій засвідчує, що українці на рівні цінностей не повністю ідентифікують себе як європейці. Для такої повноцінної самоідентифікації має бути завершений проект наскрізної демократизації соціуму, держави, громадянського суспільства. Тож сьогодні потреба демократії для українського трансформаційного суспільства є питанням фактичного збереження України в якості держави, нації, соціокультурного суб'єкта світових процесів.

\section{ЛITЕРАТУРА}

1. Андрущенко В. П. Світанок Європи: Проблема формування нового учителя для об'єднаної Європи XXI століття. К. : Знання України, 2011. $1099 \mathrm{c}$.

2. Кривошеїн В. В. Вплив «Революції гідності» на політичну та правову культуру українського суспільства // Вісник Національного університету «Юридична академія України імені Ярослава Мудрого». Серія : Політологія. 2016. № 2 (29). С. 37-58.

3. Полисаєв О. П. Соціальні інститути перехідних суспільств: специфіка трансформаційних процесів // Наукові записки НаУКМА. 2016. Т. 186, Політичні науки. С. 30-37.

4. Бабкіна О. В. Передумови переходу до демократії: ризики транзитивного суспільства // Науковий часопис Національного педагогічного університету імені М. П. Драгоманова. Серія 22. Політичні науки та методика викладання соціально-політичних дисциплін. Збірник наукових праць. 2015. Вип. 17. С. 3-11.

5. Transition to democracy. Constitutions of the New Independent States and Mongolia / Edited by The International Institute for Democracy. Strasbourg : Council of Europe Publishing, 1997. 508 p.

6. D’Anieri P. Understanding Ukrainian Politics: Power, Politics, and Institutional Design. London : Routledge, 2015. 312 p.

7. Воднік В. Д. Ментальні трансформації в сучасному українському суспільстві // Вісник Національного університету «Юридична академія України імені Ярослава Мудрого». Серія: Політологія. 2017. № 2 (33). C. 317-320.

8. Aslund A. How Ukraine Become a Market Economy and Democracy. Washington : Peterson Institute for International Economics, 2009. 345 p.

9. Мадрига Т. Б. Свропейські цінності та ціннісні орієнтації українського суспільства: проблеми співвідношення // Думка. Прикарпатський вісник НТШ. 2015. № 3(31). С. 96-103. 
10. Лютко Н. В. Політична реклама та ціннісні оріснтації суспільства в контексті електорального вибору громадян // Нова парадигма. Філософія. Політологія. Соціологія. К. : Вид-во НПУ ім. М. П. Драгоманова. 2010. Вип. 94. С. 155-163.

11. Буцевицький В. Проблеми політичної культури в Україні в процесі державотворення // Нова політика. 1999. № 1. С. 48-51.

12. Траверсе О. Політичне лідерство, національна еліта і практика модернізації суспільства // Політичний менеджмент. 2006. № 1. С. 27-36.

\section{REFERENCES}

Andrushchenko, V. P. (2011). The Dawn of Europe: The Problem of Forming a New Teacher for a 21st Century United Europe. Kyiv: Znannia Ukrainy. [In Ukrainian].

Kryvoshein, V. V. (2016). Impact of the Revolution of Dignity on the political and legal culture of Ukrainian society. Visnyk Natsionalnoho universytetu "Iurydychna akademiia Ukrainy imeni Yaroslava Mudroho”. Seriia: Politolohiia. (Bulletin of the National University "Yaroslav the Wise Law Academy of Ukraine". Series: Political Science). Kharkiv : Pravo, № 2 (29), 37-58. [In Ukrainian].

Polysaiev, O. P. (2016). Social Institutions of Transition Societies: The Specificity of Transformational Processes. Naukovi zapysky NaUKMA. (NaUKMA Scientific Notes), V. 186, Politychni nauky, 30-37. [In Ukrainian].

Babkina, O. V. (2015). Prerequisites for transition to democracy: risks of a transitive society. Naukovyi chasopys Natsionalnoho pedahohichnoho universytetu imeni M. P. Drahomanova. Seriia 22. Politychni nauky ta metodyka vykladannia sotsialno-politychnykh dystsyplin. Zbirnyk naukovykh prats. (Scientific journal of M. P. Dragomanov National Pedagogical University. Series 22. Political Science and Methods of Teaching Socio-Political Disciplines. Collection of scientific works). Kyiv: Vydavnytstvo NPU imeni M. P. Drahomanova, V. 17, 3-11. [In Ukrainian].

Transition to democracy. (1997). Constitutions of the New Independent States and Mongolia. Strasbourg: Council of Europe Publishing7.

D’Anieri, P. (2015). Understanding Ukrainian Politics: Power, Politics, and Institutional Design. London: Routledge.

Vodnik, V. D. (2017). Mental transformations in modern Ukrainian society. Visnyk Natsionalnoho universytetu "Iurydychna akademiia Ukrainy imeni Ya- 
roslava Mudroho". Seriia: Politolohiia. (Bulletin of the National University "Yaroslav the Wise Law Academy of Ukraine". Series: Political Science). Kharkiv: Pravo, № 2 (33), 317-320. [In Ukrainian].

Aslund, A. (2009). How Ukraine Become a Market Economy and Democracy. Washington: Peterson Institute for International Economics.

Madryha, T. B. (2015). European values and values of Ukrainian society: problems of correlation. Dumka. Prykarpatskyi visnyk NTSh. (Opinion. Precarpathian Bulletin of the NTSh), № 3 (31), 96-103. [In Ukrainian].

Liutko, N. V. (2010). Political advertising and values of society in the context of electoral choices of citizens. Nova paradyhma. Filosofiia. Politolohiia. Sotsiolohiia. (A new paradigm. Philosophy. Politology. Sociology). Kyiv: Vydvo NPU im. M. P. Drahomanova, V. 94, 155-163. [In Ukrainian].

Butsevytskyi, V. (1999). Problems of political culture in Ukraine in the process of state formation. Nova polityka. (New policy), № 1, 48-51. [In Ukrainian].

Traverse, O. (2006). Political leadership, national elite and the practice of modernizing society. Politychnyi menedzhment. (Political management), № 1, 27-36. [In Ukrainian].

\section{Yevhenia Riabeka}

external doctorate student of National Pedagogical Dragomanov University Kyiv, Ukraine; e-mail: riabeka20@ukr.net; ORCID: https://orcid.org/00000002-9812-0574

\section{Problems of the european democratic axiology development in the ukrainian society}

\section{Abstracts}

The strengthening of the independence of the Ukrainian state relates to the need to solve several urgent economic, political, socio-cultural problems. In politics, these problems are concentrated on the concept of "democracy". Strengthening democracy with the need to strengthen the openness of the Ukrainian society will contribute to the glorification of freedom. Let's take a closer look at that. When it comes to the establishment of a democratic society, governed with the rule of law, and to the institutions, rules, and procedures in Ukraine, one of the fundamental issues is the full consolidation of the Europe- 
an democratically humanistic values in the public consciousness, the mentality of the Ukrainians. Of course, historically we are a European nation, but we have been part of other states and cultures for a long time, where axiological guidelines differed significantly from those of Europe, which, in our view, hinders the integration of our country into the single family of European nations. The author analyses various dimensions of Ukrainian values' ambivalence which creates big struggles within Ukrainian society, so these are predetermined not by regional or national identity, but ideological and axiological preferences. The author claims that in such a complex worldview and axiological situation the Ukrainian people should choose the priorities of freedom, responsibility, solidarity, tolerance, dignity, and rule of law. This choice is greatly complicated by the poverty of the national economy and the general poverty of the population. In addition, there is a significant number of global obstacles. In modern information and technological civilization, it is difficult to be engaged in self-education, value self-education because an unlimited number of ways of action, ethical and aesthetic variations are offered. Beside such a pluralism of ways of doing and living the development speed of the First World countries could disable the nations which belong to other geopolitical and axiological clusters to overtake the developed countries and could condemn them to permanent degradation outside of the progress. This analysis and consideration of the problem of the European democratic axiology development allows to draw a conclusion that the necessity of democracy for the Ukrainian transformational society is not only the declared reference point but also the vital necessity on which the survival of the Ukrainians as independent, authentic, self-sufficient nation actually depends which is interesting for other European countries.

Keywords: human, values, culture, education, European identity, democracy. 